1967

\title{
Ideas and Interests: Businessmen and the Interstate Commerce Act
}

Edward A. Purcell Jr.

New York Law School, edward.purcell@nyls.edu

Follow this and additional works at: https://digitalcommons.nyls.edu/fac_articles_chapters

Part of the Banking and Finance Law Commons, and the Law and Economics Commons

\section{Recommended Citation}

54 Journal of American History 561 (1967)

This Article is brought to you for free and open access by the Faculty Scholarship at DigitalCommons@NYLS. It has been accepted for inclusion in Articles \& Chapters by an authorized administrator of DigitalCommons@NYLS. 


\title{
Ideas and Interests: \\ Businessmen and the Interstate Commerce Act
}

\author{
EdWard A. Purcell, JR.
}

\section{$\mathrm{H}$}

ISTORIANS have generally seen the Interstate Commerce Act of 1887 as the first major step on the road to federal regulation of business. While much of the rhetoric of American politics painted the issue in terms of "the people" or "the farmers" against "business," scholars have long been aware of the inadequacy of that view. Rather than opposing all government regulation, businessmen were often involved in sponsoring and supporting such legislation. Within the last two decades historians have published several important studies concerning the origin and purpose of the Interstate Commerce Act of 1887. Lee Benson, studying the New York State movement toward regulation of the roads, was able to delineate the impact of railroad development on various economic interest groups in the state and explain the conflict generated among them. He focused mainly on merchants, especially those in New York City, and their fight for more favorable freight rates. "New York merchants," he concluded, "constituted the single most important group behind the passage of the Interstate Commerce Act."1

More recently, Gabriel Kolko finished an examination of federal regulation from 1877 to 1916 , which concentrated on the machinations and motives of railroad leaders. The railroads were ruining themselves by cutthroat competition, Kolko argued; and hence they actually sought government regulation to stabilize their industry and to make it more profitable. He amply demonstrated that many railroad men both accepted the premise of federal regulation and strongly supported certain proposed laws. Although railroad managers were obviously not alone in urging federal action and often disagreed among themselves, Kolko maintained that "the rail-

This article received the OAH's Pelzer Award for 1967. Mr. Purcell is assistant professor of speech in the University of California, Berkeley.

${ }^{1}$ Lee Benson, Merchants, Farmers, \& Railroads: Railroad Regulation and New York Politics, 1850-1887 (Cambridge, 1955), 212. 
roads, not the farmers and shippers, were the most important single advocates of federal regulation from 1877 to $1916 . " 2$

It was "businessmen" and not "the people" or "farmers" who were the most important advocates of federal regulation, Benson and Kolko agreed; but, of course, they disagreed over which businessmen were most important. Other historians, examining the role of businessmen in the nineteenth century, have generally concurred that economic changes caused by the growth of rail transportation forced various groups to support federal regulation. ${ }^{3}$ A study of the relationship between the competitive economy of the latenineteenth century and the ideas of American businessmen would clarify the attitude of various groups toward government regulation as well as suggest more accurately the meaning and importance of the Interstate Commerce Act. Obviously, nonbusiness groups endorsed and influenced legislation for their own motives; but the purpose here is to examine only the reaction of American businessmen to the railroad problem and to relate their responses to the complexity of the economic system in which they were caught.

During the last quarter of the nineteenth century, American businessmen operated in an impersonal economic structure. In order to meet their competition, individuals whose businesses depended on shipping goods had to control as much as possible their major transportation connections. The rapid and far-reaching railroad system, which had developed after the Civil War, altered older economic relationships and placed many businessmen at a competitive disadvantage. The railroads, for example, diverted much trade from the water routes that followed the Great Lakes and the Erie Canal, and deprived merchants along the waterway of much of the business they had previously enjoyed. ${ }^{4}$ In addition to disrupting trade channels, the roads offered cheap, long-haul transportation that enabled distant merchants to compete with smaller businessmen who had earlier been able to control their local markets. Flour millers in St. Louis and Chicago, for instance, took advantage of low through-rates in order to compete for southern markets. Millers in Nashville, a local center, lost much of their market,

${ }^{2}$ Gabriel Kolko, Railroads and Regulation, 1877-1916 (Princeton, 1965), 3.

${ }^{3}$ See below, and especially Edward Chase Kirkland, Men, Cities and Transportation: $A$ Study in New England History, $1820-1900$ (2 vols., Cambridge, 1948), I, 496, 503-04, 507-08, 514, 517, 523; Charles N. Glaab, Kansas City and the Railroads: Community Policy in the Growth of a Regional Metropolis (Madison, 1962), chapters I and II, and 174-75, 189-92; Gerald D. Nash, "Origins of the Interstate Commerce Act of 1887," Pennsylvania History, XXIV (July 1957), 181-90.

${ }^{4}$ Benson, Merchants, Farmers, and Railroads, 30-36; Frederick Merk, "Eastern Antecedents of the Grangers," Agricultural History, 23 (Jan. 1949), 1; Weekly Nortbwestern Miller, 21 (April 9, 1886), 350; Edward C. Kirkland, Industry Comes of Age: Business, Labor, and Public Policy, 1860-1897 (New York, 1961), 98. 
including Atlanta, a traditional customer, and suffered greatly as a result. ${ }^{5}$ Moreover, the complicated rate structures worked new hardships on many individuals and areas. The grain merchants of Pittsburgh lost much of their trade when the railroads began charging ten cents per hundred pounds more for grain from Chicago to Pittsburgh than they did on the much longer haul from Chicago to New York. Later, both the Pittsburgh Chamber of Commerce and the Grain and Flour Exchange heartily endorsed the Interstate Commerce Act, including the controversial long-and-short-haul clause. ${ }^{6}$

Businessmen recognized the importance of the railroads, and those who were not in a position to influence railroad policy but who depended on railroad service, feared and resented the rate discriminations and the power that characterized the transportation system. Even Poor's Manual, a staunch advocate of both railroad practices and interests, admitted that the charge of discrimination was the major complaint made in all quarters against the roads. ${ }^{7}$ When the developing railroad system added the threat of potentially ruinous rate differentials to the already highly competitive and dynamic economy, those businessmen who were unable to take advantage of such differentials began to consider the desirability of government regulation. That truth was further substantiated when the biggest shippers, who could command rebates and profit from the differentials, were almost alone in opposing government regulation. ${ }^{8}$

The widespread support for federal legislation did not mean, however, that most businessmen agreed on the specific type of law that was needed. Frank J. Firth, president of the Erie and Western Transportation Company, implicitly recognized the diversity and conflict among businessmen when he testified before Senator Shelby M. Cullom's committee investigating interstate commerce in 1885 . Firth attempted to defend the roads and at the same time place them in a position superior to their many antagonists. "The transporter or merchant appearing before you," he politely told the senators, "speaks from the narrow field of observation within which this modern science of division of labor has confined him." ${ }^{9}$ Since each businessman saw only the one aspect that influenced his own business, Firth argued, then such a man could not give a comprehensive analysis. Firth's obvious conclusion was that the Cullom committee should not listen

${ }^{5}$ House Exec. Docs., 44 Cong., 2 Sess., No. 46, Part II (Serial 1761), 51.

"Kirkland, Industry Comes of Age, 98; Cong. Record, 49 Cong., 2 Sess., 385 (Jan. 5 , 1887).

${ }^{7}$ Henry V. Poor, Manual of the Railroads of the United States for 1882 (New York, 1882), ix.

${ }^{8}$ Kolko, Railroads and Regulation, 34.

${ }^{9}$ Senate Reports, 49 Cong., 1 Sess., No. 46, Part II (Serial 2357), 464. 
to complaining merchants but should rely instead on railroad men-those who understood the whole situation and knew all of the facts necessary to formulate an interstate commerce law.

Spokesmen for those businessmen who feared rate discrimination disagreed wholeheartedly with Firth and espoused their own brand of federal railroad regulation. Not all of them were enthusiastic about government interference, but their experience told them it was necessary. William $\mathrm{H}$. Beebe, a member of a Chicago merchant firm, represented those diverse shipping groups when he addressed the Cullom committee. "While I do not lean very much toward paternal legislation on the part of the Government," he explained, "still I am decidedly of the opinion that when the railroads begin to touch the point of discrimination, regulation by a commission or by some other governmental agency would be beneficial."10

The question of discrimination was puzzling and complex. Railroad men and shippers engaged in and suffered from various planned and purposeful discriminations. The whole transportation system also almost unavoidably resulted in widespread inequalities, which were themselves unintentional and accidental. Geographical location, size of shipments, competition from other transportation systems, and varying railroad overhead all combined to make uniform rates an impossible goal. The new railroad network pulled local merchants inextricably into a complex web of trade patterns, forcing them to compete with distant rivals. Trade areas overlapped more and more until a dozen cities could serve one section of the country that had previously relied on one local center. ${ }^{11}$ Individuals throughout the nation whose business depended on the shipment of goods had to have favorable transportation costs, not just for growth and profits, but for survival.

The foundation of the transportation system lay in the five great trunk lines that tied the East to the West and Midwest and dominated the transportation of goods in intersectional and international trade. Each directly connected the trans-Appalachian region with one or more of the major eastern seaports: Boston, New York, Philadelphia, and Baltimore. The merchants in these cities engaged in a constant struggle with one another to protect and increase their share of the western trade, just as the trunk lines fought with one another over the available freight. Thus, in 1881, the New

${ }^{10}$ Ibid., Part II (Serial 2357), 653.

${ }^{11}$ House Exec. Docs., 48 Cong., 2 Sess., No. 7, Part II (Serial 2294), 8; Kirkland, Industry Comes of Age, 51, 66-68, 78, 98, 100, 126-27; House Exec. Docs., 44 Cong., 2 Sess., No. 46, Part II (Serial 1761), 49; House Exec. Docs., 46 Cong., 3 Sess., No. 7, Part II (Serial 1966), 8-10. For the fight between various localities for railroad connections see Carter Goodrich, Government Promotion of American Canals and Railroads, 1800-1890 (New York, 1960), 234, 237, 259-61, 282-83; Earl S. Beard, "Local Aid to Railroads in Iowa," Iowa Journal of History, 50 (Jan. 1952), 1-34. 
York Central cut its rates in an attempt to increase its freight and to win more trade for New York. The other trunk lines responded with similar cuts, and soon rate war followed. Businessmen in the four cities entered the fight immediately because they feared that their competitors would secure more favorable differentials. ${ }^{12}$ Both the railroads and the ports tried to work out agreements on differentials in the interest of peace and steady profits, but their failure led to constant dissatisfaction and rate-cutting. Conflicts even divided the interests of the trunk lines from those of their original terminals. The various roads found it profitable to carry goods to rival cities, and the merchants of the terminal cities took advantage of cheaper rates from other lines. ${ }^{13}$

Edward Kemble, a Boston merchant, was typical of the businessmen who needed low rail rates. When the rates were temporarily disadvantageous, he called for government regulation to improve his competitive position. "Massachusetts and a good portion of New England are, in my judgment, to-day laboring under an outrageous railroad discrimination," he claimed. ${ }^{14}$ The railroads were favoring New York with relatively cheap rates, Kemble argued, and they were thus robbing Boston of her share of the trade. Earlier, when the differentials weighed against New York, the city's Chamber of Commerce had petitioned Congress for relief from the unjust discriminations that were injuring "the producing, commercial, and other interests of the state, and particularly those of the City of New York." 15 Railroad executives, too, disliked the open competition and despaired at the continual and debilitating rate wars. Even Albert Fink, the staunch supporter of private pooling, came to believe that only federal legislation could establish a viable pooling system. ${ }^{16}$

Competition among producers and shippers in the Midwest and the South was as sharp and unrelenting as it was in the East. Chicago and St. Louis, the major centers in the Midwest, had a long history of commercial rivalry that the advent of railroad transportation only intensified. ${ }^{17}$ They were challenged, however, by an increasing number of regional competitors

${ }^{12}$ Benson, Merchants, Farmers, and Railroads, 29-79; Kirkland, Men, Cities, and Transportation, I, 502-08, 512-16.

${ }^{18}$ House Exec. Docs., 45 Cong., 3 Sess., No. 32, Part III (Serial 1857), 146.

${ }^{14}$ Senate Reports, 49 Cong., 1 Sess., No. 46, Part II (Serial 2357), 379.

${ }^{15}$ Henry V. Poor, Manual of the Railroads of the United States, 1881 (New York, 1881), lii.

${ }^{16}$ House Exec. Docs., 44 Cong., 2 Sess., No. 46, Part II (Serial 1761), 12; D. T. Gilchrist, "Albert Fink and the Pooling System," Business History Review, 34 (Spring 1960), 38; Thomas C. Cochran, Railroad Leaders, 1845-1890: The Business Mind in Action (Cambridge, 1953), 161-62, 165, 192.

${ }^{17}$ Wyatt Winton Belcher, The Economic Rivalry Between St. Louis and Chicago, 18501880 (New York, 1947), especially chapters IV, V, IX, X. 
which were anxious about their own share of the growing commerce. Kansas City, Louisville, Cincinnati, New Orleans, Peoria, and many other cities struggled for prominent places in the burgeoning commerce of the Midwest. Under the influence of shippers in Minneapolis and St. Paul, for example, the Chicago, Burlington \& Northern lowered rates to improve the competitive position of the Twin Cities against Chicago and St. Louis. ${ }^{18}$ After 1876, merchants in Milwaukee, enjoying a rate differential over competitors in Chicago, cut into their business until the latter were able to command equal rates. ${ }^{19}$

One of the most spectacular examples of the expansion of competition created by railway growth centered on the lucrative trade which St. Louis enjoyed in Latin American products-especially sugar, molasses, crockery, and coffee-that were shipped through $\mathrm{New}$ Orleans and up the Mississippi, the shortest trade route from the South. Chicago businessmen challenged the merchants of New Orleans and St. Louis by allying with importers in Baltimore and winning the support of the trunk lines seeking additional westbound freight. Utilizing freight reductions from Baltimore of up to ninety percent, Chicago merchants were able to offer lower delivery prices on goods from Latin America and to divert the trade from New Orleans and the Mississippi route, thus profiting themselves, the trunk lines, and the Baltimore importers. ${ }^{20}$

Businessmen in smaller cities and interior distribution points refused to accept, without putting up a strong fight, the loss of trade and influence that the expansion of competition caused. They supported both state and federal regulation as a means of preserving their economic positions. The businessmen in Dubuque, Iowa, and other river towns led the fight for state regulation to protect themselves from roads offering low through-rates to Chicago. They received support in the interior, not so much from the Grangers but from the small businessmen in the prairie towns who also suffered from rate discriminations. Together they were able to pass the famous Iowa Granger law, bringing the roads under state control. ${ }^{21}$ In 1877 , when the railroads imposed a temporary embargo on the city's grain, the Kansas City Times vigorously attacked the move as "a vital stab at the business interests of the city." Earlier the Journal of Commerce, a local business publication, had urged a federal antipooling law to protect local

${ }^{18}$ Weekly Nortbwestern Miller, 22 (Aug. 27, 1886), 204.

${ }^{19}$ House Exec. Docs., 44 Cong., 2 Sess., No. 46, Part II (Serial 1761), 51-52.

${ }^{20}$ Ibid., 52-53.

${ }^{21}$ George H. Miller, "Origins of the Iowa Granger Law," Mississippi Valley Historical Review, XL (March 1954), 658-59, 664, 668, 678-80. 
interests. ${ }^{22}$ Merchants in Montgomery, Selma, and Mobile joined forces in 1881 to establish Alabama's first railroad commission, which they hoped would protect their endangered commercial positions from the consolidation of local roads under the control of the Louisville and Nashville. ${ }^{23}$ Braxton Bragg Comer, who later led the movement for further state regulation in Alabama, was himself a victim of the expansion of competition. Rivals in St. Louis and other northern centers had ruined his Birmingham milling trade and forced him out of business. ${ }^{24}$

Discriminatory railroad practices existed not only between competing businessmen in different regions but also between merchants in the same city or area. In New York the Chamber of Commerce opposed two key provisions of the proposed Interstate Commerce Act, while the members of the Board of Trade and Transportation supported them both. ${ }^{25}$ The result of the situation, declared the president of the New York Produce Exchange, had been to aid certain favored merchants, who were often large stockholders in the roads, to the detriment of their local competitors. ${ }^{26}$ Such practices caused great damage to the helpless merchants, he believed, and were wholly unjust. Perhaps there is no stronger motivation than the combination of a feeling of injustice with the fear of unprofitability. A Chicago businessman stated it clearly: "It is simply in effect letting one man steal another man's business." 27

Rate policies often divided local businessmen in different lines of commerce. In Boston, for example, where most merchants who dealt in goods shipped by rail were angry about differentials made in favor of New York and other cities, the exporting merchants stood strongly in favor of the existing rates. William $\mathrm{H}$. Lincoln, manager of a Boston steamship line, explained that his export trade had grown immensely after the railroads began shipping large quantities of goods from the West. Since the roads had cut the rate from Chicago to Boston on goods intended for export, Boston had gained an advantage over New York in the export trade. ${ }^{28}$ Kemble, acknowledging that exporters benefitted from existing rates, declared that the majority of Boston businessmen were not helped by the

${ }^{22}$ Glaab, Kansas City and the Railroads, 176, 177.

${ }^{23}$ James F. Doster, Alabama's First Railroad Commission, 1881-1885 (University, Ala., 1949), 30-31, 34-35, 180; James F. Doster, Railroads in Alabama Politics, 1875-1914 (University, Ala., 1957), 8, $20-24$.

"James F. Doster, "The Conflict over Railroad Regulation in Alabama," Business History Review, 28 (Dec. 1954), 338.

${ }_{2 \pi}$ Cong. Record, 49 Cong., 2 Sess., 477, 791 (Jan. 10, 18, 1887).

${ }^{26}$ Senate Reports, 49 Cong., 2 Sess., No. 46, Part II (Serial 2357), 214.

${ }^{27}$ Ibid., Part II (Serial 2357), 592.

"Ibid., Part II (Serial 2.357). 354. 
rates. "It is of no benefit to her merchants," he broadly declared, "it is of no benefit to her banks, it is of no benefit to her insurance companies, it is of no benefit to her real-estate interests." 29

Again, at other times, rate differentials divided the interests of those in the same business. From the standpoint of the origin of the Interstate Commerce Act, one of the most important local conflicts existed in western Pennsylvania between the Rockefeller forces and the competing independent oil producers. Through the ability to command exorbitant rebates from the railroads, Rockefeller was slowly forcing his rivals out of business. In self-defense the independents joined to bring pressure on their congressman for government regulation of the railroads, especially for an antirebate law. Their campaign led directly to the introduction of John $\mathrm{H}$. Reagan's bill into the House of Representatives in $1878 .^{30}$ While that bill eventually became the basic House bill and was in large part made law in 1887 , it came too late for the independent oil producers who had surrendered to Rockefeller by 1880 .

Other business groups throughout the country joined the attack on discriminatory railroad practices. Merchants handling dairy goods in the northcentral states complained because they were charged much higher rates on butter and cheese than the merchants shipping meats or lard had to pay. ${ }^{31}$ There seemed to be no defense against such injustices, they argued, and they called for federal action to end them. Steamboat operators also objected to the railroad practice of cutting rates to the bare minimum when competing with water lines. The railroads could make up their losses on noncompetitive lines; the steamships could not. By such methods, explained J. B. Wood, an agent of the St. Louis and New Orleans Anchor Line, railroads tried to ruin the steamship lines. ${ }^{32}$ Even those men engaged in the jewelry trade were critical of the railroads and wanted some type of regulation. The roads generally did not want to bother with the small but valuable jewelry trunks and made it very difficult for the jewelers to transport their goods. ${ }^{33}$ That was unfair, the jewelers argued; they were willing to assume the risk for their goods, if they could only get the reasonable transportation services that the roads had previously refused them.

The new system of railroad transportation not only established a wider sphere of competition and made advantageous freight rates a major factor in

${ }^{29}$ Ibid., Part II (Serial 2357), 382. See also Cong. Record, 49 Cong., 2 Sess., 634-35 (Jan. i4, 1887).

${ }^{30}$ Nash, "Origins of the Interstate Commerce Act of 1887," 181-84, 189.

${ }^{31}$ Senate Reports, 49 Cong., 1 Sess., No. 46, Part II (Serial 2357), 657.

${ }^{32}$ Ibid., Part II (Serial 2357), 1398.

${ }^{33}$ Ibid., Part II (Serial 2357), 446. 
commercial success but also fragmented the interests of American businessmen. Gradually, businessmen made alliances on the basis of their attitude toward government regulation of the railroads, each operating from his own motives and for his own interests. The struggle over the role government should play in the railroad system divided businessmen into four main groups. The largest of them, composed of the men who suffered from unfavorable differentials, strongly urged government action to protect their interests or, as they phrased it, to insure the public welfare. "In our judgment the time has arrived," read a statement of the Toledo Produce Exchange, "when Congress should assume its undoubted right and duty to the whole of the country, to supervise the whole system of transportation in this country." ${ }_{34}$ The Peoria Board of Trade was even more specific: "The best method of preventing extortion and discrimination," it declared, "is by means of stringent laws passed by Congress." ${ }^{35}$

Often businessmen who favored strong legislation to control interstate commerce revealed marked antipathy to the railroads. Eastern merchants shared much the same attitude traditionally associated with midwestern farmers. The railroads "have come to the conclusion apparently that they are masters of the situation," charged James H. Seymour, representing the New York Mercantile Exchange, "and they treat it as if it was a business of their own, a private business, not a public business, and do not seem to regard themselves as doing business for the public." ${ }^{36}$ James Spear, a Philadelphia manufacturer, took another tack, striking at an obvious failing of the roads. "My complaint," he stated, "would be simply a general complaint of bad management of all the railroads in the United States. . . "37

The great majority of the businessmen who favored government regulation gave wholehearted support to the idea of a watchdog commission that would be empowered to prohibit unfair railroad practices. In large part, general confidence in the commission system stemmed from relatively successful experiences, especially in Massachusetts, during the previous decade. "It seems reasonable," remarked J. D. Seeberger, a wholesale hardware dealer in Des Moines, Iowa, referring to the commission plan, "that, according to the working of the commission in this State, it might operate successfully in an enlarged sphere." 38 Businessmen wanted effective regulation, not some untried experiment. They felt that the commission system had proved itself, and they were willing to support it.

${ }^{34}$ Ibid., Part I (Serial 2356), appendix, 71

${ }^{35}$ Ibid., Part I (Serial 2356), appendix, 103.

${ }^{36}$ Ibid., Part II (Serial 2357), 207.

${ }^{37}$ Ibid., Part II (Serial 2357), 473

${ }^{3 s}$ Ibid., Part II (Serial 2357), 986 
Many businessmen disagreed about the exact amount of control that the commission should exercise; yet they wanted it to have enough authority to be effective. Many suggested that either the commission be given judicial powers to decide law suits brought against the roads or have its findings made prima facie evidence in any court of law in the nation. Few would have gone along with M. A. Fulton, a Wisconsin merchant, who urged that Congress should pass an "absolute law" which would establish rates throughout the country. ${ }^{39}$ Such a plan was much too rigid.

A second, smaller group of businessmen took a more cautious approach. Their economic positions demanded some type of government regulation, but they were unsure as to both the type of legislation needed and all the ramifications of such action. "My opinion is that Congress should go pretty slow upon the subject of regulating, or attempting to regulate, freight rates," declared E. O. Stanard, a St. Louis mill owner, "especially at this time, when everything is so depressed." 40 Charles Ridgely, president of the Springfield Iron Company, expressed the same concern that government action might harm business activity in general. "Less damage to business is likely to occur from doing too little in the way of regulation of interstate commerce than from doing to much," he told the Cullom committee. ${ }^{41}$ Still, under the circumstances, both men acknowledged the need for federal regulation.

In spite of their fear that regulation might cause further economic hardships and an inbred suspicion of government interference, many businessmen allowed economic necessity to overcome most of their doubts. Bradstreet's best represented many of the businessmen in that group; and although the magazine did not support the Cullom bill, it did concede that "With this demand for the passage of a national law, there exists a general acquiescence even on the part of railroad men themselves in the principles of a national railroad commission." 42

A third group, much smaller than the first two, formed around those men - predominantly railroad men and investors in weaker railroad bonds-who advocated government regulation not for the protection of the public but for the welfare of the struggling roads. James D. Furber, the manager of the Boston and Maine Railroad, asked Congress for a law prohibiting rebates. "They are very annoying in your accounts and annoying to the railroads," he explained; "there is nothing fair about it to the public or to the

${ }^{39}$ Ibid., Part II (Serial 2357), 1248.

${ }^{40}$ Ibid., Part II (Serial 2357), 852.

${ }^{41}$ Ibid., Part I (Serial 2356), appendix, 65.

42 Bradstreet's: A Journal of Trade, Finance and Public Economy, XV (Jan. 15, 1887), 
railway. ..." ${ }^{43}$ W. G. Raoul, president of the Central Railroad and Banking Company of Georgia, went even further by suggesting that Congress should pass laws to insure fairer profits for the railroads and a just return on capital investments. ${ }^{44}$ Furber and Raoul drew support from such railroad presidents as John King of the Erie, J. C. Clarke of the Illinois Central, Frank S. Bond of the Reading, and George B. Roberts of the Pennsylvania, all of whom favored federal regulation that would aid the lines suffering from overexpansion and rate wars. ${ }^{45}$

The major railroad journals gave voice to the same demands and the same goals. They defended the roads as essential to the well-being of the American economy and argued that they deserved to be protected from harmful legislation. The Railway World declared that the roads had "rendered an immense amount of service to the American people, and done more than any other single agency to generate national prosperity." 46 Not content with such self-praise, the Railway Age insisted that: "The vast interests represented in and connected with the operation of railways are entitled not only to protection from injustice but to friendly fostering by the government." ${ }_{47}$ The other journals took similar stands, admitting both the right and need for federal action, but contended that the legislation should help rather than hinder the railroads. ${ }^{48}$

Although Chauncey M. Depew of the New York Central had declared that "all the leading railroad men, I think, admit the principle of government supervision and are anxious for it," railroad men clearly disagreed with the type of legislation that most other businessmen had in mind. ${ }^{49}$ The economic structure of late nineteenth-century America forced railroad men, as it had forced other businessmen, to seek the protection of the federal government. ${ }^{50}$

A fourth distinct group of businessmen rejected the idea of federal regulation of the railroads and were driven by two entirely different motives. One such group of men opposed railroad regulation because they thought that any such legislation would only aid the railroads to the detriment of

${ }^{43}$ Senate Reports, 49 Cong., 1 Sess., No. 46, Part II (Serial 2357), 333.

${ }^{44}$ Ibid., Part I (Serial 2356), appendix, 147, 148-49, 156.

${ }^{45}$ James W. Neilson, Shelby M. Cullom, Prairie State Republican (Urbana, 1962), 115. See also Kolko, Railroads and Regulation, 34-41.

${ }^{46}$ Railway World, 29 (June 20, 1885), 578.

${ }^{4 i}$ Railway Age, 13 (June 22, 1888), 390.

4s Railroad Gazette, 18 (Dec. 17, 1886), 874; Railway Review, 27 (Jan. 22, 1887), 46, 47.

${ }^{49}$ Railway Review, 27 (Jan. 8, 1887), 21.

${ }^{50}$ For the types of problems railtoad men faced see Julius Grodinsky, Transcontinental Railway Strategy, 1869-1893: A study of businessmen (Philadelphia, 1962), 226-69; Kolko, Railroads and Regulation, 7-20, 35; Gilchrist, "Albert Fink and the Pooling System," 24-49. Railroad men were not hesitant to call upon the government for help when the situation demanded it. See Cochran, Railroad Leaders, 192. 
everyone else. Regulation in their minds was actually a crutch for the roads. Francis B. Thurber, a New York wholesale grocer who had long been interested in the problems of transportation, spoke for this group when he told the Cullom committee that the railroads were the chief supporters of federal regulation: "The trouble is, with many railroad men who have failed in the tasks required of them, to pay dividends on the capitalization, that they want now to appeal to the Government to help them out." ${ }_{51} \mathrm{He}$ advised them to stay with the doctrine of competition, even though it might work temporary hardship on some people. A similar view was expressed by J. H. Walker, a Massachusetts manufacturer, who stated that "great injury ... would be done to the country by any effort to protect the owners of the railroads." ${ }_{2}$ Although they overestimated by far the number of railroad men who favored the final Interstate Commerce Act, Thurber and Walker were well aware of the attempt made by railroad men to secure the passage of a favorable regulatory law.

The other group that opposed government regulation argued from both practical and theoretical bases; they combined the plea that the complexities of railroad management were beyond the competence of legislation with their adherence to principles of laissez faire and free enterprise. Although the members of that group may have believed firmly in their laissez-faire principles, they were also usually individuals who prospered under the status quo-either spokesmen for companies that enjoyed profitable rate differentials or owners of high-dividend railroad stocks. Charles A. Pillsbury, one of the major and most successful shippers in the nation as well as one who commanded lucrative rebates, was a perfect example. "We have no complaints to make," he truthfully informed the committee. ${ }^{53}$

Charles E. Perkins, president of the Chicago, Burlington, and Quincy Railroad, was the most outspoken member of that small but determined group. Not only did he refuse to admit the existence of any but the rarest case of railroad abuse but also he attacked just about every proposal of regulation that had been suggested. He denounced the plan of publicized railroad rates, denied the possible efficacy of any scheme of rate-fixing, attacked uniform accounting laws, justified pools and price discriminations, and rejected the idea of annual railroad reports to the government. ${ }^{54}$

"The wisdom of any legislation which may look to changing the conditions which have produced results on the whole so beneficial," he confidently stated, "may well be doubted." The real evil, he suggested, was

${ }^{51}$ Senate Reports, 49 Cong., 1 Sess., No. 46, Part II (Serial 2357), 293.

${ }^{32}$ Ibid., Part II (Serial 2357), 335.

${ }^{53}$ Ibid., Part II (Serial 2357), 1240.

${ }^{54}$ Ibid., Part I (Serial 2356), appendix, 216-20. 
that an erroneous public opinion might force the passage of laws that would seriously harm the whole economic structure of the nation and very likely lead to complete government ownership of the railroads. "Among the evils of Government ownership and control," he predicted, "would undoubtedly be higher charges and increased taxation." 55 Perkins' resentment against the Interstate Commerce Act died hard. Two years after its passage, in a pamphlet published by the C. B. \& Q., he called the law unwise, impractical, and one of the greatest burdens under which the roads had to operate..$^{56}$

Perkins had one prominent counterpart. The Commercial and Financial Chronicle led a determined opposition against government regulation and defended a strict version of laissez faire. In 1874, commenting on the business recession, it had noted:

trade is suffering from those general sources of commercial disturbance which have been often demonstrated to be as far beyond the reach of human legislation as are the meterological [sic] forces that bring about a late spring or a wet summer, or a copious harvest. As the world grows wiser men are getting to recognize more and more the marvellous wisdom of the great doctrine of the French economists, "laissez-faire et laissez-passer." 57

Following its guiding principle, the Cbronicle continually attacked the idea of government regulation of the railroads. "Hardly anything can be more dangerous just now than any further extension of Congressional power," it declared in 1879; and two years later, it noted that federal regulation "can be anything but a failure we have but the slightest expectation." 58 When Congress was preparing the final version of the Interstate Commerce Act in 1886, the Chronicle angrily insisted that "The measure as proposed is so full of crudities and so totally at variance with all economic and we might almost say moral laws that it passes comprehension how an intelligent body of men can countenance or recommend certain of its provisions." 59

In spite of the air of certainty and authority that marked its pages, the Cbronicle represented only a small minority of the businessmen concerned with interstate transportation. Few American businessmen shared the journal's belief in the benevolent workings of laissez-faire economics, at least in regard to the problem of the railroads. They were much more interested in operating their businesses more efficiently and profitably. Most business groups saw government regulation as a necessary means to that end.

${ }^{65}$ Ibid., Part I (Serial 2356), appendix, 225.

${ }^{56}$ Nation, XLVIII (Feb. 14, 1889), 136-37.

${ }^{67}$ Commercial and Financial Cbronicle, 18 (May 30, 1874), 538-39.

${ }^{58}$ Ibid., 28 (Feb. 22, 1879); 185; ibid., 32 (Jan. 29, 1881), 112. See also ibid., 14 (Feb. 17, 1872), 210-11; ibid., 22 (Feb. 19, 1876), 171-72.

${ }^{59}$ Ibid., 43 (Dec. 18, 1886), 731. 
Businessmen showed little interest in philosophical distinctions. The great majority of them rejected laissez-faire economics and cared little for the theory of the survival of the fittest, often considered the basis of business philosophy. Hardly anyone who testified before the Cullom committee even mentioned the concept. Businessmen were much more concerned with the evils of rate discrimination, the effects of pooling, and the value of longand-short-haul legislation than they were with the laws of nature, the benevolence of competition, or the loss of an abstract liberty. The very few men who even made reference to the concept clearly rejected it. John $\mathrm{H}$. Devereux, the president of the Cleveland, Columbus, Cincinnati, \& Indianapolis Railroad, who claimed that "absolutely the railroad interests of this country are going to destruction," believed that regulation was necessary for the good of the roads. ${ }^{60}$ The chaos in the railway industry was "not to be remedied by waiting upon 'the survival of the fittest." "That "misapplied phrase" had nothing to do with the condition of the railroads, Devereux explained, and was of no help in attempting to improve the situation. "The law of "survival' may apply to animals," he emphasized, "but not to railroads. . . "61 George W. Parker, vice president and general manager of the St. Louis, Alton, \& 'Terre Haute Railroad, expressed the same pragmatic attitude when he said simply that 'the theory of the 'survival of the fittest' does not apply to railroads. ..." 62 Parker, like Devereux, accepted the necessity of regulation and urged pooling as the solution to railroad conflict. Even Poor's Manual, which complained of the difficulties that afflicted the roads in 1885 , declared firmly that the theory of survival did not work in the railroad business. "Railroads," the editors argued, "unfortunately, seem to reverse the rule of 'the survival of the fittest,' to "the survival of the unfittest." "63

Businessmen were thus more interested in solving particular problems than they were in adhering to any "business philosophy." Perhaps on a different issue they might have appealed to the theory of survival of the fittest or to the principles of free competition, but when it was clearly contrary to their interests they readily abandoned both of them. ${ }^{64}$ There could

${ }^{60}$ Senate Reports, 49 Cong., 1 Sess., No. 46, Part II (Serial 2357), 825.

${ }^{81}$ Ibid., Part II (Serial 2357), 819

${ }^{62}$ Ibid., Part II (Serial 2357), 911.

${ }^{63}$ Henry V. Poor, Manual of the Railroads of the United States for 1885 (New York, 1885), v.

${ }_{64}^{64}$ Twenty years ago businessmen were often seen as apostles of Spencerianism and social Darwinism; more recent scholarship has tended to cast doubt on much of that interpretation. See especially Edward C. Kirkland, Dream and Thought in the Business Community, 1860-1900 (Ithaca, 1956), 13-15; Irvin G. Wyllie, The Self-Made Man in America: The Myth of Rags to Riches (New Brunswick, 1954), 83-87; Irvin G. Wyllie, "Social Darwinism and the Businessman," Proceedings of the American Pbilosopbical Society, 103 (Oct. 1959), 629-35. 
be no question that the vast majority of them viewed some type of government action as a necessity for their economic welfare.

When Congress was seriously debating the interstate commerce bill in 1885 and 1886 , businessmen throughout the nation supported the idea of regulation in overwhelming numbers. During the first session of the Fortyninth Congress petitions from business groups were almost unanimous in favoring federal action. ${ }^{65}$ Criticism grew only after the Senate-House conference had worked out a final proposal. Then, businessmen who would have been harmed by the specific type of regulation Congress had accepted protested against the offending provisions in the bill, especially against the antipooling and long-and-short-haul clauses. ${ }^{66}$ Since those merchants located close to markets favored the long-and-short-haul clause, most opposition to that provision came from shippers in western cities such as Chicago and Springfield. ${ }^{67}$ These opponents of the interstate commerce bill did not attack the idea of regulation; they complained only that certain parts of the bill would be harmful to their economic positions. Regulation would be fine, they argued, so long as it was "helpful" regulation.

The opposing reactions of millers in St. Louis and Minneapolis, rivals in the flour trade, were typical of the reactions among competing businessmen across the nation. Since Minneapolis had a great advantage over St. Louis before 1887 , due to the availability of cheap water transportation and the ability of her millers to force large rebates from the competing roads, Minneapolis flour merchants were unanimous in attacking the conference billsaving special condemnation for the long-and-short-haul clauses.$^{68}$ St. Louis merchants, however, hoping that the new provisions would enable them to compete more favorably with the northern center, favored the bill and expected it to accomplish "a great deal of good." The Weekly Nortbwestern Miller, a journal of the Minneapolis milling interests, frankly summarized the opposing reactions by observing that the interests of the two cities seemed "diametrically opposed." The editors were not surprised that most St. Louis businessmen supported the bill. ${ }^{69}$

Although many railroad men had supported legislation favorable to the roads, most of them agreed that the interstate commerce bill was not the

${ }^{\text {ex }}$ Cong. Record, 49 Cong., 1 Sess., 344, 1011, 2023, 1684, 2899, 2783, 4073 (Dec. 21, 1885, Feb. 1, March 4, Feb. 23, March 25, 29, May 3, 1886).

${ }^{66}$ Ibid., 49 Cong., 2 Sess., 350, 385, 474, 477, 511, 560, 631, 926, 1173 (Jan. 5, 8, 10, $11,13,24,29,1887)$. For petitions favorable to the final act see ibid., 49 Cong., 2 Sess., $350,385,598,791$ (Jan. 4, 5, 13, 18, 1887).

${ }^{6 \tau}$ Neilson, Shelby M. Cullom, 111.

${ }^{8}$ Gilchrist, "Albert Fink and the Pooling System," 47-48; Weekly Nortbwestern Miller, 23 (Jan. 21, 1887), 60.

${ }^{69}$ Weekly Nortbwestern Miller, 23 (Jan. 21, 1887), 60. See also Cong. Record, 49 Cong., 2 Sess., 479, 511, 636 (Jan. 8, 10, 14, 1867). 
law they had wanted. Although Kolko's assertion that railroad men agreed to the principle of federal regulation is undoubtedly true, his conclusion that the roads favored the final bill and for the most part "welcomed the signing of the new railroad law" is quite doubtful. ${ }^{70}$ Kolko himself admits that John Murray Forbes and William Bliss, two leading railroad men, were hostile to the new act. They were not alone. The presidents of most roads were dissatisfied with the House-Senate compromise bill and worked against its passage. They focused their opposition on Congress, bringing special pressure to bear on their senators and representatives. The presidents of all five of the Vanderbilt lines opposed the bill throughout 1887 and into $1888 .^{71}$ Jay Gould and Leland Stanford denounced it. Samuel Sloan, president of the Delaware, Lackawanna, and Western, claimed that "The bill is impracticable and ought not to pass," while Clement A. Griscom, a director of the Pennsylvania, thought that there had already been too much legislation. ${ }^{72}$ "The Inter-State Commerce Bill ...," wrote Frederick J. Kimball, president of the Norfolk and Western, "will, I think, break up the entire through transportation business of the country and will work great harm to all business interests." 78

Moreover, the actual positions of the major railroad journals ranged from general dissatisfaction to bitter hostility. The Railroad Gazette, the least antagonistic of the major industry journals, tended to accept the new law but still did not like it and declared that "it hampers business as badly as a much severer law" and could do "a great deal of harm."74 Although that journal claimed that the new law could be the basis for something better, its whole argument was that only if the roads obeyed the law could they show both the legislators and the public how bad it actually was, and hence bring about "something better." 75

The Railway Review, which showed much less restraint in its attack on the new law, stated that it was passed "by the votes of men who do not believe in it," because "their votes were forced from them by popular clamor." Referring to charges made during debate on the bill, the Review agreed that members of Congress "did not like the law" and that the bill was one "that nobody understood, that nobody wanted."" 76 It also charged that "The bill, as it now stands, places too great, too autocratic power in the hands of five men, and subjects them to too severe temptations." It was

${ }^{70}$ Kolko, Railroads and Regulation, 45.

"Cochran, Railroad Leaders, 197, 198.

${ }^{72}$ Neilson, Shelby M. Cullom, 116.

${ }^{18}$ Cochran, Railroad Leaders, 374.

${ }^{74}$ Kolko, Railroads and Regulation, 45, 46; Railroad Gazette, 19 (Feb. 18, 1887), 112.

${ }^{75}$ Railroad Gazette, 19 (April 1, 1887), 216-17.

${ }^{76}$ Railway Review, 27 (Jan. 22, 1887), 46. 
"unwise and unjust." The Review went far beyond the attacks of the other industry journals. "In fact, if the act had been devised by the enemies of the government and of the people of the United States," it declared on January 22, 1887, "the most merciless malice and the most careful deliberation could hardly have hit upon a measure more deadly and far-reaching in its effects."' 77

The other leading industry journals also expressed grave doubts and deep fears over the proposed measure. The Reagan-Cullom bill "will seriously jeopardize the efficiency of numerous links of the existing through railway systems," declared the Railway World. "That any important movement in such a direction will be a serious error can scarcely be doubted." The mainspring for much of the regulatory legislation, the World asserted, "seems to be furnished by a supposition that plans can be devised whereby the nation can be enriched by impoverishing the railways." "This is sorry work for an American congress," the World concluded. ${ }^{78}$ "The injurious effects of the interstate commerce law ought to cause serious reflection on the part of the makers and supporters of this law," declared the Railway Age, which continued to oppose the act into 1888 and $1889 .{ }^{79}$ "The law has put a premium on reckless competition and incited all kinds of sharp practices" in the competitive railroad industry. "The utter heartlessness of the law" marked it off from all other regulatory attempts. "In some of its features the interstate commerce law defies the natural principle of justice and equity, and hence it cannot endure without reform." 80 Even the commission which was supposed to interpret the law "conservatively" drew the scorn of that journal. The members "seem to have moved with the current of popular opinion into the feeling that the interstate commerce law was intended solely for the repression and punishment of the railway interest," the Railway Age complained bitterly, "and not to any degree for its protection." 81

Thus there was widespread and vocal opposition to the Interstate Commerce Act on the part of many railroad executives. That they generally welcomed the bill appears doubtful. Granted, some railroad managers-for various reasons-did either support or accept the act. The point is that there was strong and determined opposition and much division of opinion. Railroad men were neither satisfied with the bill generally nor were they its strongest supporters. Very likely the great division of opinion among the

"Ibid., 48, 47.

${ }^{8}$ Railway World, 31 (Jan. 8, 1887), 27.

${ }^{79}$ Railway Age, 13 (Sept. 21, 1888), 601.

${ }^{80}$ Ibid., 13 (Dec. 21, 1888), 810.

${ }^{81}$ Ibid., 14 (Jan. 11, 1889) , 17. 
roads gave other interests a greater weight than they might otherwise have had against a united railroad lobby.

Just as the railroads were not the major advocates behind the Interstate Commerce Act, neither were the New York merchants nor any other single group. Support for government regulation was, in fact, widespread among businessmen; and that near unanimity was more important in forcing federal action than was the endorsement by any one group. The primary dynamism behind the drive for regulation was the threatening pattern of economic changes that forced most businessmen in all lines of commerce to seek federal intervention as a means of protecting their own individual interests. The desire for economic protection was the one and only unifying force among those who supported regulation; and it cut across all commercial and geographic boundaries and swept up the great majority of American businessmen into an effective movement for the assertion of their interests through the federal government.

It was neither "the people" nor "the farmers"- nor even "the businessmen"- who were responsible for the government regulation of railroads. Rather, it was many diverse economic groups in combination throughout the nation which felt threatened by the new national economy and sought to protect their interests through the federal government. Often they were unsure of the exact means to be used, but they were clear about the end they hoped to accomplish. The railroads were necessary for the prosperity of most businessmen, and they intended to force the roads to serve their purposes. The so-called "business philosophy" of the late-nineteenth century meant little to most businessmen, at least when it conflicted with their practical commercial needs. "We are not aware that there is the slightest principle involved in the question," observed the Banker's Magazine in discussing the issue of railroad regulation; "it is one purely of selfinterest." 82 Such a broad statement might perhaps be harsh, yet it surely described the attitude of American businessmen toward the Interstate Commerce Act.

${ }^{82}$ Banker's Magazine, 42 (March 1888), 660. 